\title{
Attempts on artificial induction of sexual maturation of sterlet (Acipenser ruthenus) and identification of late spermatogenesis stage in hermaphroditic fish
}

\author{
T. Müller · I. Ittzés · Zs. Szőke • Á. Hegyi · E. Mészáros · K. K. Lefler • \\ Z. Bokor · B. Urbányi · B. Kucska (i)
}

Received: 12 December 2017/Accepted: 18 May 2018/Published online: 26 June 2018

(C) The Author(s) 2018

\begin{abstract}
Most of the 27 species of sturgeons are endangered or close to extinction which is connected to habitat degradation, water pollution and overfishing. Conservation programmes are facing the problem of late maturation which can be reached between 5 and 11 years depending on the species and gender. The aim of our study was to investigate the possibility of shortening the sexual maturation using hormonal administration, and measure the blood serum hormone content to distinguish different genders and maturation stages. There was no effect of a 20 -week-long hormonal treatment (10 mg carp pituitary/bodyweight $\mathrm{kg} / \mathrm{week}$ ) on the sexual maturation. The number of females was relatively high $(67.6 \% n=23)$ and the number of males was relatively low $(11.8 \%, n=4)$. Moreover, the number of hermaphroditic fish was surprisingly high $(20.6 \%, n=7)$ and appeared independently from hormone administration. Hermaphroditic fish had fully developed spermatozoa and could be distinguished by the increased level of testosterone hormone in blood serum.
\end{abstract}

Keywords Sterlet $\cdot$ Sexual maturation $\cdot$ Hermaphroditism $\cdot$ Serum hormone profile

\section{Introduction}

Several studies have been published on the reduction of sturgeon populations. Water pollution, overfishing, and habitat degradation at spawning and nursery grounds are the most important factors of this decrease. In spite of very determined conservation efforts to save the sturgeon, their share in the world catch is quite modest, and it is decreasing (Bronzi et al. 2011). Due to these facts, most of the 27 species of sturgeons are endangered or close to extinction in all habitats (Birstein 1993). To carry out biological studies on sturgeon the sterlet (Acipenser ruthenus) is attractive because of its freshwater status, its small size and therefore a low cost for maintenance, and its early sexual maturation (Williot et al. 2005). The original aim of our study was to investigate the possibility of artificial induction of sexual maturation using hormonal administration. In this

T. Müller · I. Ittzés · Á. Hegyi · E. Mészáros · K. K. Lefler · Z. Bokor · B. Urbányi

Department of Aquaculture, Faculty of Agricultural and Environmental Sciences, Szent István University, Gödöllő 2100, Hungary

Zs. Szőke

NARIC-Agricultural Biotechnology Institute, Gödöllő 2100, Hungary

B. Kucska $(\bowtie)$

Department of Aquaculture, Faculty of Agricultural and Environmental Sciences, Kaposvár University, Kaposvár 7400, Hungary

e-mail: kucska.balazs@ke.hu 
case, the entire process of gametogenesis has to be induced. Since Yamamoto and Yamauchi, (1974) obtained fertilised eggs and larvae from Japanese eel (Anguilla japonica) by using long-term hormone administration from immature phase to induce ovulation phase, many researchers have succeeded in obtaining eel larvae in other Anguilla species. The secondary aim of the study was to investigate the blood serum hormone content to check in vivo the maturation stage of the different genders with and without artificial induction of sexual maturation.

\section{Materials and methods}

\section{Conditions}

Fish originated from the Research Institute for Fisheries, Aquaculture and Irrigation, Szarvas, Hungary. All of them were reared in intensive conditions from larvae to the age of 14 months. At this time, 34 fish were selected randomly and transported to the Department of Aquaculture of Szent István University. Fish were kept in a 2000-L tank connected with a 700-L filter tank (static bed bio-filter). The initial water temperature was $18{ }^{\circ} \mathrm{C}$ and has been increased $22{ }^{\circ} \mathrm{C}$ until the end of experiment. Daily feeding of fresh Chironomus was applied during the experiments (4 months).

\section{Treatment}

Seven fish were dissected at the start of maturation experiments (initial control). Sixteen fish were treated with abdominal carp pituitary injections (10 mg carp pituitary/bodyweight $\mathrm{kg}$ ) after anaesthesia by clove oil (Syzygium aromaticum) once a week for 20 weeks. 11 fish were not treated and reared as negative control in the same tank. The animals were kept in a photoperiod close to natural seasonal rhythm.

Histology and hormone measurement

Samples of gonads were fixed in 8\% formalin and Bouin's solution, and 5- to 7- $\mu \mathrm{m}$-thick histological sections were stained with haematoxylin-eosin. In addition, serum profile parameters [testosterone (T), progesterone (P4), 17-beta-estrogen (E2)] were measured by using protocol of their Technical Data Sheets. Catalogue no. of steroid-kits: P4 CatNo.: REF3000131 (Soft Flow Hungary Ltd.) E2: CatNo: DNOV003 (Novatec Gmbh.) T: CatNo: DNOV002 (Novatec Gmbh).

\section{Statistical analyses}

Statistical analyses of gonadosomatic index GSI, oocyte diameter and serum hormone concentrations were carried out by independent sample $t$ test in SPSS v22 for Windows. Treatment means were compared using $p=0.05$ for significance.

\section{Results and discussion}

According to the histological and blood serum profile investigation of gonads, the following observations were made. There was no effect of weekly carp pituitary extract administration on artificial induction of sexual maturation of sterlet compared to control fish considering the GSI and oocyte developmental phase. In this experiment stock the ratio of hermaphroditic fish was surprisingly high $(20.6 \%, n=7)$. Hermaphroditic fish appeared independently of hormone administration (Table 1). Mature hermaphroditic fish, which contained fully developed spermatozoa in their testes (Fig. 1), appeared independently of hormone administration. The ratio of males was low (11.8\%) and all were immature independently of hormone administration. In our study, the hermaphrodites were 14 months old with fully developed testis, which indicate that microscopy analysis can be revealed their intersexual stage in earlier developmental phase. Moreover, the increased serum testosterone (T2) profile which can be observed at hermaphroditic fish could easily be distinguished from male 
Table 1 Summarised data of the experiment

\begin{tabular}{|c|c|c|c|c|c|c|}
\hline Treatment & & Females & Males & Hermaphrodite & $\begin{array}{l}\text { GSI females and } \\
\text { hermaphrodite }(\%)\end{array}$ & $\begin{array}{l}\text { Oocyte diameter } \\
(\mu \mathrm{m})\end{array}$ \\
\hline \multirow[t]{2}{*}{ Initial } & No ind. & 5 & 1 & 1 & \multirow{2}{*}{$1.1 \pm 0.1^{\mathrm{a}}$} & \multirow{2}{*}{$160.1 \pm 24.1^{\mathrm{a}}$} \\
\hline & $\mathrm{BW}$ & $257.8 \pm 106.2^{\mathrm{a}}$ & 342.0 & 171.5 & & \\
\hline \multirow[t]{2}{*}{ Control } & No ind. & 8 & 1 & 2 & \multirow{2}{*}{$0.6 \pm 0.1^{b}$} & \multirow{2}{*}{$199.9 \pm 35.3^{\mathrm{b}}$} \\
\hline & BW & $296.9 \pm 43.3^{\mathrm{b}}$ & 314.9 & $280.3-359.6$ & & \\
\hline \multirow[t]{2}{*}{ Treated } & No ind. & 10 & 2 & 4 & \multirow[t]{2}{*}{$0.9 \pm 0.3^{\mathrm{a}}$} & \multirow[t]{2}{*}{$194.2 \pm 28.4^{\mathrm{b}}$} \\
\hline & BW & $372.1 \pm 56^{\mathrm{b}}$ & $294.0-407.9$ & $371.5 \pm 43.2$ & & \\
\hline \multirow{2}{*}{$\begin{array}{l}\mathrm{E} 2(\mathrm{pg} / \\
\mathrm{ml})\end{array}$} & No ind. & 5 & 2 & 4 & & \\
\hline & Mean \pm SD & $4.69 \pm 0.61^{\mathrm{A}}$ & $0.45-1.02$ & $4.16 \pm 1.46^{\mathrm{A}}$ & & \\
\hline \multirow{2}{*}{$\begin{array}{l}\text { Prog. (pg/ } \\
\text { ml) }\end{array}$} & No ind. & 5 & 2 & 4 & & \\
\hline & Mean \pm SD & $42.55 \pm 26.53^{\mathrm{A}}$ & $6.06-18.89$ & $30.52 \pm 32.52^{\mathrm{A}}$ & & \\
\hline \multirow{2}{*}{$\begin{array}{l}\text { Test. (pg/ } \\
\text { ml) }\end{array}$} & No ind. & 5 & 2 & 4 & & \\
\hline & Mean \pm SD & $4.46 \pm 1.02^{\mathrm{A}}$ & $3.44-3.89$ & $16.72 \pm 5.58^{\mathrm{B}}$ & & \\
\hline
\end{tabular}

Data by experiments marked with different superscript letter are significantly different $(p<0.05)$ according to the independent sample $t$ test

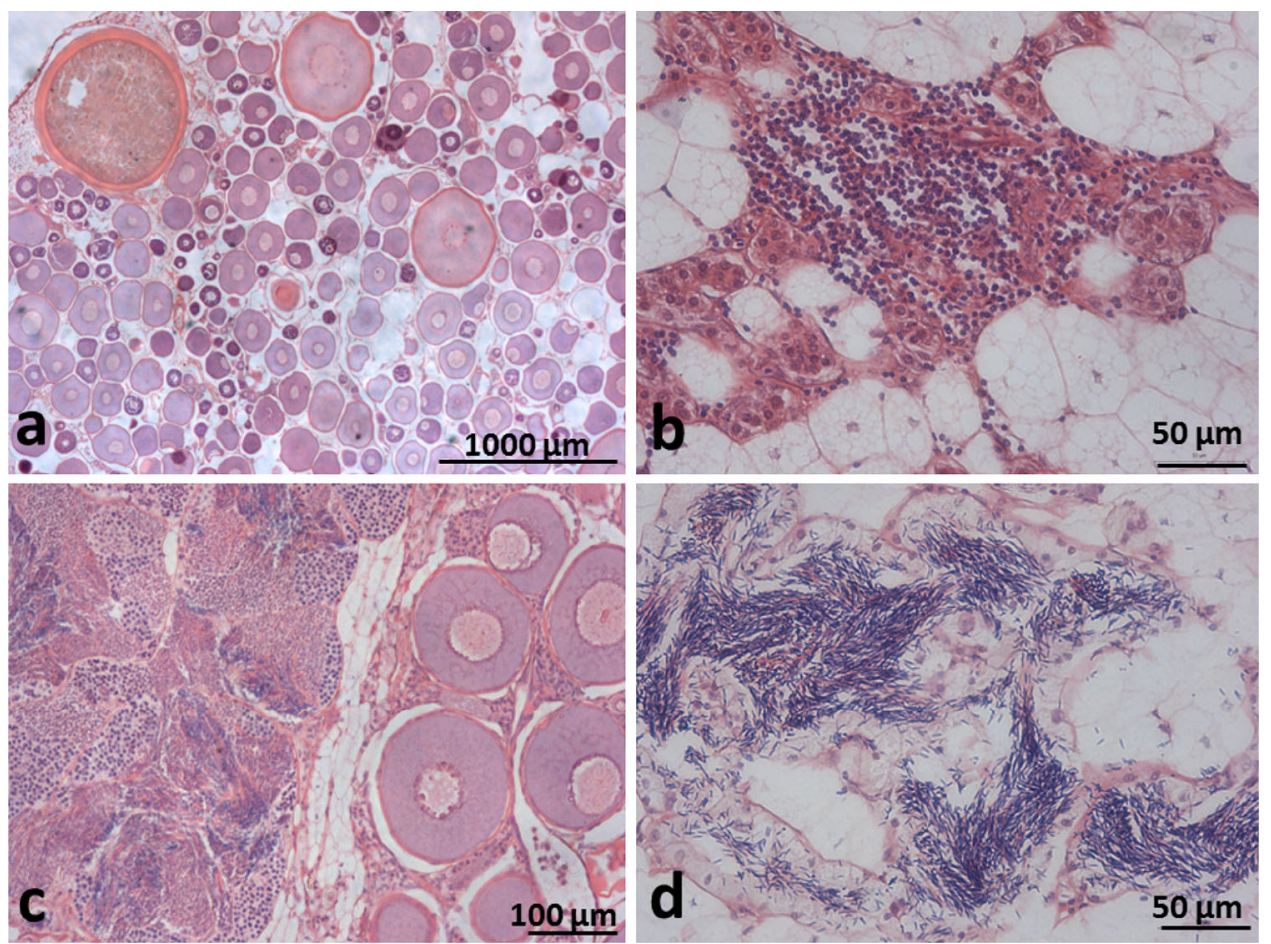

Fig. 1 Histological pictures of experimental fish: a treated and only one female which had developed oocytes (BW: 378.3 g, the largest oocytes in mid and late vitellogenic phase, the largest of them are in pre-vitellogenic stage. b Male (BW: $342 \mathrm{~g}$, larger spermatocyte and smaller spermatids); c hermaphrodite (BW: $359.6 \mathrm{~g}$, testis right of the pictures containing the whole stages of spermatogenesis and ovary contains pre-vitellogenetic oocytes); d hermaphorite (BW: $421.6 \mathrm{~g}$, full developed spermatozoa in testis)

and female fish which has immature gonads that age. According to measured plasma E2 and progesterone levels, there were no significant differences among the genders and there was no intergroup variability.

It is supposed that hermaphroditic fish produce vital and normal spermatozoa according to morphological features of spermatozoa from histological preparations (spermatozoa head length $=5.49 \pm 0.39 \mu \mathrm{m}$ ) and literature data about the hermaphrodites (Williot et al. 2005; Henne et al. 2006). Jackson et al. (2006) 
investigated several 5-year-old female Russian sturgeon (Acipenser gueldenstaedtii) and they found the ovarian component of the intersex gonad was at the pre-vitellogenic stage as in normal females, and the testis component contained spermatids and mature spermatozoa as in normal males of the same age. Williot et al. (2005) reported about the self-fertilisation in sterlet. Embryonic survival of self-fertilised eggs ranged from 0 to $70 \%$. Progeny was obtained twice. Originally the number of hermaphrodite fish was $1-5 \%$ in investigated stocks. In our study, the hermaphrodite ratio was significantly higher. However, the reason for this phenomenon is not clear. According to Jobling and Tyler (2003), wide variety of adverse environmental conditions may induce endocrine disruption, including sub-optimal temperatures, restricted food supply, low $\mathrm{pH}$, environmental pollutants, and/or parasites. The stock was reared in relatively high temperature $\left(18-22{ }^{\circ} \mathrm{C}\right)$ during their lifedays. The relatively high rearing temperature could disturb the gonad development.

According to Matshe et al. (2013), testosterone and estradiol hormone levels in A. brevirostrum with ovotestis (consisting of scattered spermatic cysts in predominantly immature ovary) were closer to levels found in immature males, even though the predominant tissue type was immature ovary. Intersex fish with testis-ova (consisting of ovarian lamellae projecting from predominantly immature testes) had elevated levels of estradiol compared to immature males. In case of zonal distribution (consisting of multiple, nearly homogenous pockets of either testicular or ovarian tissues along the gonad) had significantly lower testosterone than in mature males, and significantly higher estradiol than in mature females. In our observation, all intersex sterlets (A. ruthenus) had small mature testis tissues within immature ovary tissue and had significantly higher testosterone than in males and females, and estradiol levels close to females. Intersex $A$. gueldenstaedtii had immature ovary with scattered pockets of mature testicular tissue, where estradiol and 11-ketotestosterone hormone levels were closer to that of males (Jackson et al. 2006). Rzepkowska et al. (2014) investigated intersex Russian (A. gueldenstaedtii) and Siberian (A. baerii) sturgeons. Macroscopically, intersex gonads were recognisable from 500 days post-hatching (dph). According their observation initially, gonads with predominantly male characteristics (testis-ova) were found, but in older fish gonads with predominantly female traits (ova-testis) were more frequent. Using microscopic analysis, intersex gonads were discernible by $130-200 \mathrm{dph}$.

Intersexuality has benefits both in scientific and economical aspects. It is useful to produce inbred populations for genetic or nutrition research for instance. We suppose that the reason for these interesting features could be intensive rearing conditions (high rearing water temperature, high initial density, etc.). Valuable experiments can be carried out in caviar production if we can change the sex of hermaphrodites and males to females by manipulating them with the optimised rearing conditions.

Acknowledgements This publication has been supported by the Hungarian Government through the project of "Complex break points in the development of competitiveness of the aquaculture sector" (project number: VKSZ_12-1-2013-0078). The work was supported by the Fisheries Operative Programme III. axis "European Fisheries Fund for Renewable Fisheries" provided by the EU and Hungary and the publication is supported by the EFOP-3.6.3-VEKOP-16-2017-00008 project. The project is co-financed by the European Union and the European Social Fund.

Open Access This article is distributed under the terms of the Creative Commons Attribution 4.0 International License (http:// creativecommons.org/licenses/by/4.0/), which permits unrestricted use, distribution, and reproduction in any medium, provided you give appropriate credit to the original author(s) and the source, provide a link to the Creative Commons license, and indicate if changes were made.

\section{References}

Birstein VJ (1993) Sturgeons and paddlefishes: threatened fishes in need of conservation. Conserv Biol 7(4):773-787

Bronzi P, Rosenthal H, Gessner J (2011) Global sturgeon aquaculture production: an overview. J Appl Ichthyol 27:169-175

Henne JP, Ware KM, Wayman WR, Bakal RS, Horváth Á (2006) Synchronous hermaphroditism and self-fertilization in a captive shortnose sturgeon. Trans Am Fish Soc 135:55-60

Jackson K, Hurvitz A, Din SY, Goldberg D, Pearlson O, Degani G, Levavisivan B (2006) Anatomical, hormonal and histological descriptions of captive Russian sturgeon (Acipenser gueldenstaedtii) with intersex gonads. Gen Comp Endocrinol 148:359-367

Jobling S, Tyler CR (2003) Endocrine disruption, parasites and pollutants in wild freshwater fish. Parasitology 126(SUPPL.):S103-S108

Matshe MA, Rosemary KM, Brundage HM, O’Herron JC (2013) Reproductive demographics, intersex, and altered hormone levels in shortnose sturgeon, Acipenser brevirostrum, from Delaware River, USA. J Appl Ichthyol 29:299-309 
Rzepkowska M, Ostaszewska T, Gibala M, Roszko M (2014) Intersex gonad differentiation in cultured Russian (Acipenser gueldenstaedtii) and Siberian (Acipenser baerii) sturgeon. Biol Reprod 90(2), 31:1-10

Williot P, Brun R, Rouault T, Pelard M, Mercier D, Ludwig A (2005) Artificial spawning in cultured sterlet sturgeon, Acipenser ruthenus L., with special emphasis on hermaphrodites. Aquaculture 246:263-273

Yamamoto K, Yamauchi K (1974) Sexual maturation of Japanese eel and production of eel larvae in the aquarium. Nature 251:220-222

\section{Publisher's Note}

Springer Nature remains neutral with regard to jurisdictional claims in published maps and institutional affiliations. 